[農化 第 47 巻, 第 5 号, p. 321 326, 1973]

\title{
揮発性脂肪酸 $\left(\mathrm{C}_{1} \sim \mathrm{C}_{8}\right)$ のガスクロマトグラフ分析
}

\author{
沢村正義，橋永文男，䇤島 豊 \\ (九州大学费学部食糧化学工学科)
}

昭和 47 年 12 月 12 日受理

\begin{abstract}
Determination of Volatile Fatty Acids of $\mathrm{C}_{1} \sim \mathrm{C}_{3}$ by
Gas Chromatography

By Masayoshi Sawamura, Fumio HaShinaga and Yutaka OSAJimA

Department of Food Science and Technology, Faculty of Agriculture,

Kyushu University, Fukuoka
\end{abstract}

\begin{abstract}
Volatile fatty acids, such as formic acid which is difficult to detect by FID, acetic, propionic, isobutyric, butyric, isovaleric, valeric, caproic and caprylic acids, were trimethylsilylated and determined quantitatively by gas chromatography using hydrogen flame ionization detector (FID). Sodium salts of fatty acids were liberated with an acidifying agent in organic solvents, then esterified with the trimethylsilyl reagent. The supernatant solution was injected into the gas chromatograph.

Trichloroacetic acid was most suitable as acidifying agent on account of good efficiency of separation from related fatty acids. Acetone, rather than ethyl ether or petroleum ether, was suitable as the solvent. The lower boiling esters such as trimethylsilyl formate and acetate were stable in acetone at least 2 hours below $26^{\circ} \mathrm{C}$, and therefore it was found that the entire procedure can be carried out quantitatively at room temperature without any significant loss. The gas chromatogram on a mixture of the fatty acids showed complete resolution with good shapes of peak. The result obtained by plotting the peak area ratio versus the mole ratio showed the good linearity-relation.
\end{abstract}

(Received December 12, 1972)

\section{㒂}

言

James と Martin(2)がガスクロマトグラフで, 最初に $\mathrm{C}_{1} \sim \mathrm{C}_{18}$ の脂肪酸をメチルェステルとして睄定して以来， ガスクロマトグラフィーによ吉脂肪酸分析に関して, 多 くの報告がなされてきた，ところて，低級嗮肪酸をガス クロマトグラフで測定する場合，脂肪酸を罳接，遊離酸

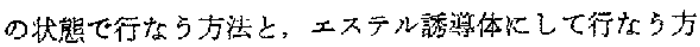
法が考えられている. 前者の方法に開して，多くの埌告

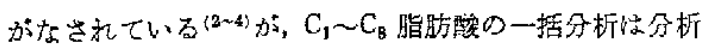
時間を長くし、テーリングを起こし中すく，䖵たギ酸 $\left(C_{1}\right)$ のイオン化電王が高く, 水素炎イオン化榆岕器 (FID) を用いた暘合，橹出不叮能なことなどの難点があ る、一方, 後者の方法、すなわらエステル誘導体として 行なら方法汇関して，最初メチルエステルによる定量化

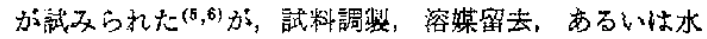

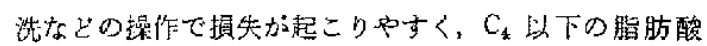

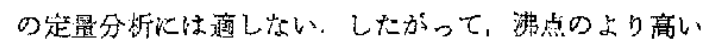

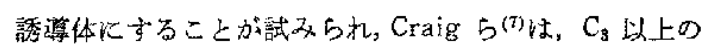
脂肪酸をブチルエステル，デシルェステル，フェナシル エステルとして，此撆惨討を行なっている．まてRalls ら ${ }^{(8)}$ は，揮発性脂肪酸をエホルェステルとして分析して いるが，この場合，溶媒から手酸を分離できない点が

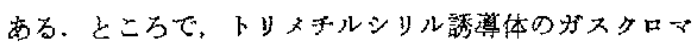
トグラフ分析は粮(9)， アミノ酸(40)，ステロイド類(11)な

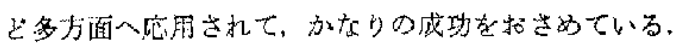

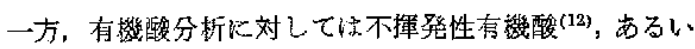
は $\mathrm{C}_{10} \sim \mathrm{C}_{18}$ の脂肪酸のトリメチルシリル化が武双られ， 粍々壀告されてきた

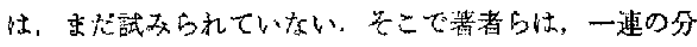




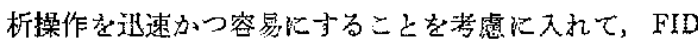
感度のない中酸を含めた $\mathrm{C}_{1} \sim \mathrm{C}_{8}$ の揮発性脂肪酸をト リォチルシリル化し，FIDによるガスクロマトダラフ分 析る陚み，啮是可べき結果が得られたので埌告する。

\section{実 験 方 法}

1. カスクロマトグラフィーの条件 装置は，水寈

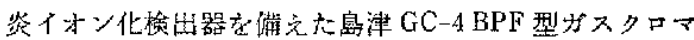
トダシフで，分離为シム性内面を5\%ジメテルジクロル シラン (DMCS) トルェン淮液でコーキングしたがラス カ 相として $5 \%$ SE-52，䞡体として 60〜80 mesh の Chromosorb W (AW DMCS 処理) を用いた。 カラム温度 は, $55^{\circ} \mathrm{C} \sim 160^{\circ} \mathrm{C}$ まで $10^{\circ} \mathrm{C} / \mathrm{min}$ 昇温とした。 キ+リけ

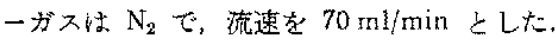

2. 試薬へキサメキルジシラザン (HMDS) とト リメチルクロルシラン (TMCS) は, ガスクロマトグラ

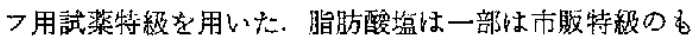
の，一部は実验空で調製したもので，いずれる水ーアセ トンで3回再結晶した。トリクロル酰酸 (TCA) は，市

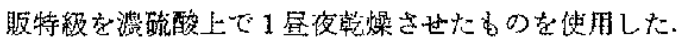
またアセトン、エチルェーテルおよび石油エーテルは，

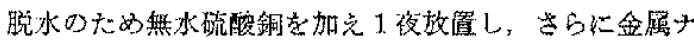
トリウムで微量の水分を除いた亦と，再蒸留したものを 用Wた。

3. エステル化上検量線和 $\sim \mathrm{C}_{8}$ の各脂䟽酸塩の 涺合物として $20 \mathrm{mg}$ 以下，内部整準としてナフタリン $1 \mathrm{mg}$, TCA $40 \mathrm{mg}$ 娄約 $5 \mathrm{ml}$ 容の共栓付遠沈管化とり,

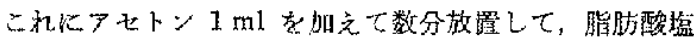

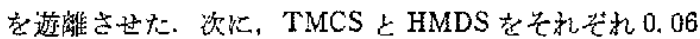

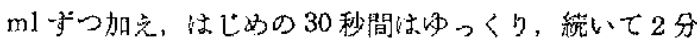
間激しく振とらしたのb，15 分間室鼬に放崖すること

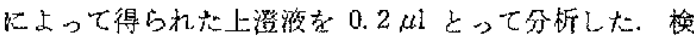

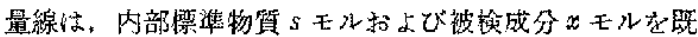
知量比含む陚料似ついてクロトグラムをとり，ピーク

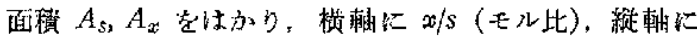
$A_{x} / A_{\varepsilon}$ (面積比) をとって，3回の平均犆加作成した。

\section{璂 験 結 果}

\section{1. 脂肪酸堛の遊離化試薬の険討}

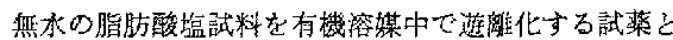
してもノー，ジー阽よびトリクロル䣫酸を選び，それらの
エステルと $\mathrm{C}_{4} \sim \mathrm{C}_{\mathrm{B}}$ 脂肪酸エステルとの分離注ついて，

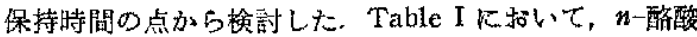
のトリメチルシリルエステルの保持時間を 1.00 とした とき，Eノクロル釄酸エステルは iso-吉草酸エステル

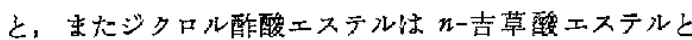

Table I. Relative Retention Values of TMS Esters of Selected Fatty Acids, Mono-, Di- and Trichloroacetic Acids

\begin{tabular}{lc}
\hline \multicolumn{1}{c}{ TMS Ester } & Relative $R_{v}$ \\
\hline n-Butyrate & 1.00 \\
Isovalerate & 1.31 \\
n-Valerate & 1.72 \\
Caproate & 2.35 \\
Monochloroacetate & 1.28 \\
Dichloroacetate & 1.70 \\
Trichloroacetate & 2.25 \\
\hline
\end{tabular}
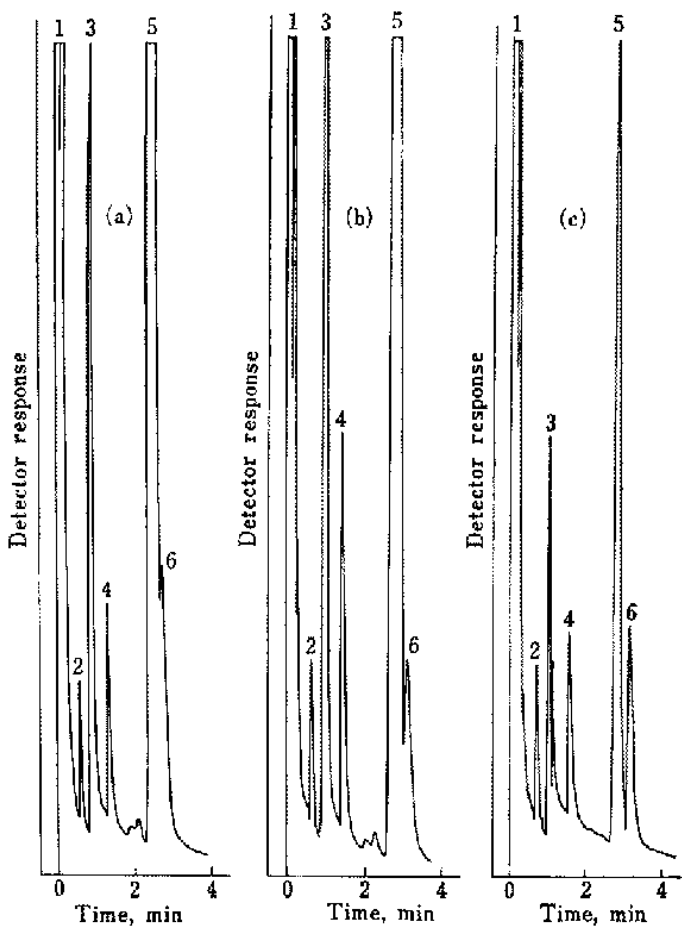

Fig. 1. Chromatograms Showing Separation of HMDS and TMS Ester of Propionic Acid.

Each of HMDS and TMCS were added to $1 \mathrm{mg}$ of propionate and $2 \sim 4 \mathrm{mg}$ of formate and acetate as follows: (a) $0.2 \mathrm{ml}$, (b) 0.1 $\mathrm{ml}$, (c) $0.06 \mathrm{ml}$. column temperature : $55^{\circ} \mathrm{C}$, sample size : ca. $0.2 \mu$ l. peaks in order of appearance : (1) acetone, (2) formate, (3) TMCS, (4) acetate, (5) HMDS, (6) propionate. 


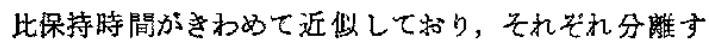
ることは困難であった. しかしトリクロル酶酸エステル は、良接したカブロン酸ェステルと比保持時間で 0.10 差があり，活注完全に分陮することがかかった，したが って以後の实験では，遊離化試薬としてトリクロル瞃酸 を使用しだ。

2.トリメチルシリル (TMS) 化試菜と脂肺酸エステ 几上の分離

TMCS 技よび HMDS は低渄点で保持時間が短いが， これらと近似した保持時間をるつギ酸、醉彯招よびプロ ピオン酸のエステルについて，カラム湿揽 $55^{\circ} \mathrm{C}$ 一定 にして相互の分離を拾討した．Fig. 1 から明らかなよら

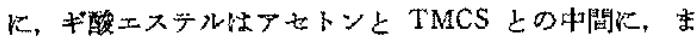

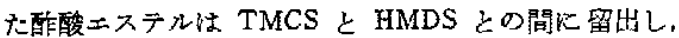
TMCSの量には関係なく，旮れぞれ良好な分蜼を示し た.しかしながらプロピオン酸エステルの場合は, HMDS

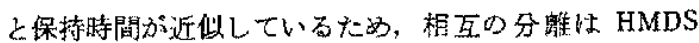
の量によって支配された。すなわら Fig. 1 (a)，(b) の ごとく, HMDS 家それでれ $0.2 \mathrm{ml} ， 0.1 \mathrm{ml}$ 使用したと きは，分離が不完全であった，しかし，

Fig. 1 (c) のよう飞 HMDS $0.06 \mathrm{ml}$ 使用したとき，良好な分離を示した。 HMDS とプロピオン酸エステルについ て分羅の程度をあ方わす分解能 $R$ を $\mathrm{D}$. Ambrose 5の式(16)加占求方と Fig. 1

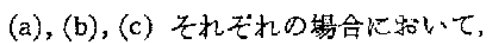
$R=0.6,0.9,1.1$ であった. HMDS 0.06 ml は，遊離化試藻として使用する TCA の最大量 $40 \mathrm{mg}$ をTMS 化するに要する 量の約2 倍强で市り，反応を行なら火充 分な量である。 なる。，HMDS $0.03 \mathrm{ml}$

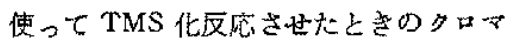
トグラムには，HMDSのピークは出現せ

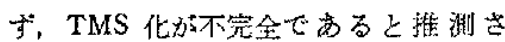
れた。

\section{3. 反応溶媒の険㶦}

沸点の低小有機溶媒の中からアセト

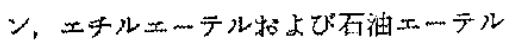
の3種の溶媒を選ひ，脂肪酸試料として ク一酪酸以ついてガスクロマトグラフ分 析を行ない，专の精度の点から，それそ わの溶媒汇ついても比较検討しだ・ガス
クロマトグラフィーの条件は，実験方法1のごとくで南 り，7回くり返し夷験で内部標集のナフタリン対する n-酷酸エステルのピーク面㺓比加ら標潗㾝差劣求める と, Table II の結果が得られな. 表から明らかなよう

Table II. Precision in Analysis of TMS Ester of $n$-Butyric Acid in Some Kinds of Solvents

\begin{tabular}{cccc}
\hline$n$ & \multicolumn{3}{c}{ Peak area ratio } \\
\cline { 2 - 3 } $\begin{array}{c}\text { Reaction in } \\
\text { acetone }\end{array}$ & $\begin{array}{c}\text { Reaction is } \\
\text { ethyl ether }\end{array}$ & $\begin{array}{c}\text { Reaction in } \\
\text { petroleum } \\
\text { ether }\end{array}$ \\
\hline 1 & 1.55 & 1.40 & 1.30 \\
2 & 1.57 & 1.31 & 1.33 \\
3 & 1.54 & 1.35 & 1.32 \\
4 & 1.55 & 1.36 & 1.32 \\
5 & 1.56 & 1.32 & 1.31 \\
6 & 1.53 & 1.36 & 1.34 \\
7 & 1.55 & 1.33 & 1.31 \\
Mean & 1.55 & 1.35 & 1.32 \\
Std. dev. & 0.012 & 0.027 & 0.013 \\
\hline
\end{tabular}

Mole ratio ( $n$-butyrate/naphthalene) : reaction in acetone ; 2.72 , reaction in ethyl ether ; 2.51 , reaction in petroleum ether; 2.53 .
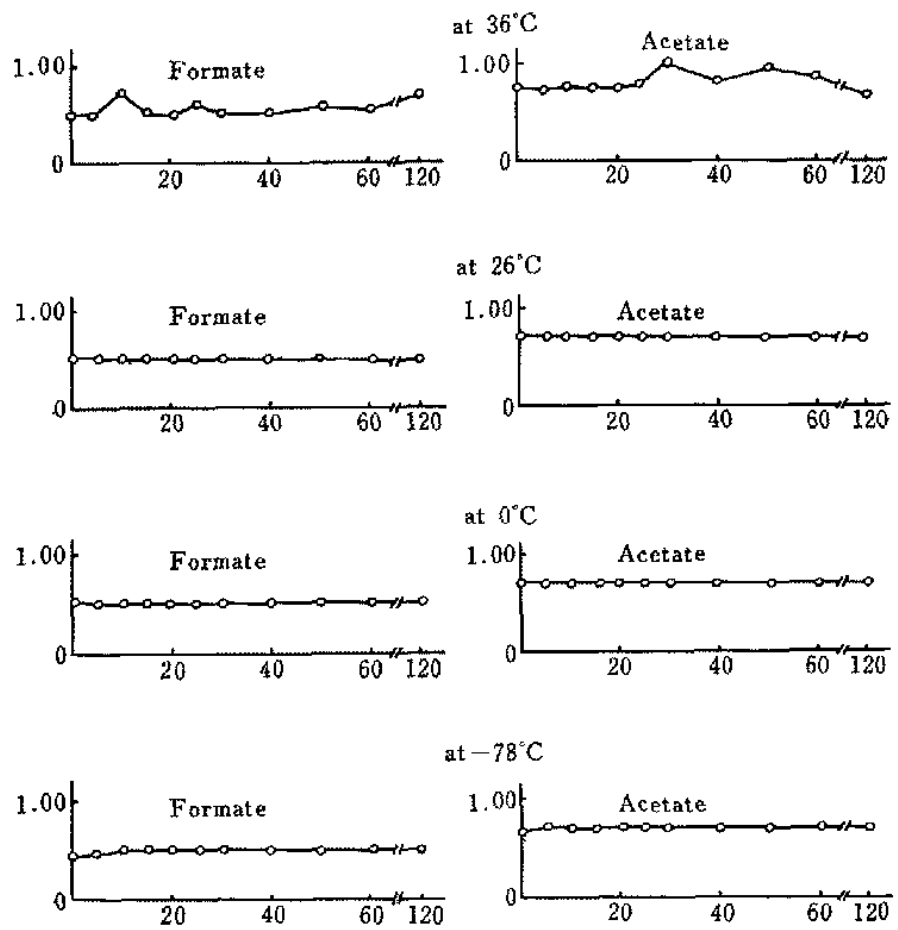

Fig. 2. Stability of TMS Esters of Acetic and Formic Acid at Various Temperatures.

Column temperature : $55^{\circ} \mathrm{C}$, abscissa : minute, ordinate : relative peak area ratio to toluene. 
飞，3種の溶棊の中でアセトンと石油ェーテルを使用し

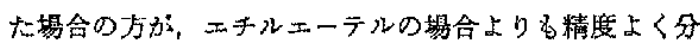
析されらることがわかった，しかし脂㕫酸の中徃塩陚料

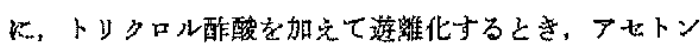
中では速中かに反応が進んだが，石油エーテル中では反 応が終了するまでに器㭙間を要したししたがって以後の 実験には，溶楪としてアセトンを崔用した。

\section{4. 反湿度と時間}

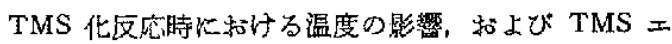
ステルの経時安定性について検討した，すなわちFig. 2 飞牧いて $36^{\circ} \mathrm{C}, 26^{\circ} \mathrm{C}, 0^{\circ} \mathrm{C}$, 拈よび $-78^{\circ} \mathrm{C}$ の 4 条件下

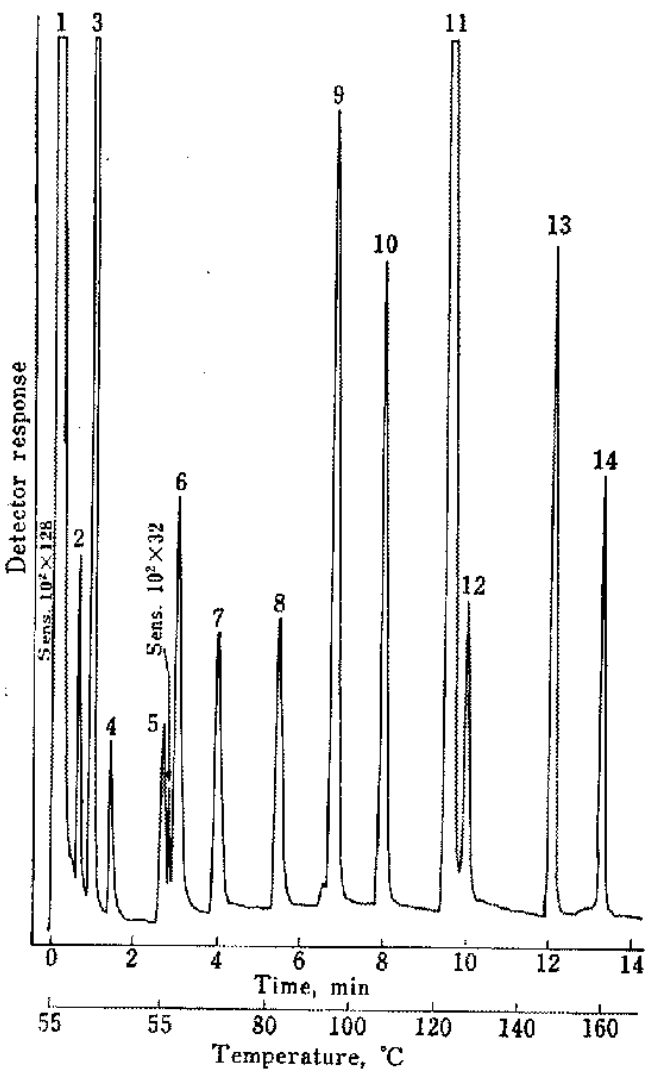

Fig. 3. Chromatogram of a Mixture of TMS Esters of $C_{1}$ to $C_{8}$ Eatty Acids.

Column size : $\phi 4 \mathrm{~mm} \times 3 \mathrm{~m}$, column packing: $5 \% \mathrm{SE}-52$ on Chromosorb W $(60 \sim$ $80 \mathrm{mesh}$ ), temperature: $\quad 55 \sim 160^{\circ} \mathrm{C}$ (programme rate $: 10^{\circ} \mathrm{C} / \mathrm{min}$ ), peaks in order of appearance : (1) acetone, (2) formate, (3) TMCS, (4) acetate, (5) HMDS, (6) propionate, (7) jsobutyrate, (8) n-butyrate, (9) isovaleate, (10) n-valeate, (11) TCA, (12) caproate, (13) naphthalene, (14) caprylate.
で反応を行なるせ，それぞれについて内部標準のトルエ

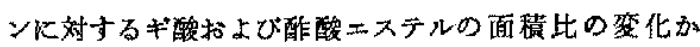
ら，TMS ェステルの安定性を経時的炕追跡した，その

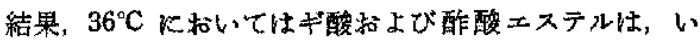
ずれすばらつきがみられた。これ虫，特そらく生したェ ステルの捙発性にも上つく据失によるるのと推察され る. しかしながら $26^{\circ} \mathrm{C}$ 以下では，2 時間放置後でる TMS エステル4安定であり，加つ恬らつき認められ

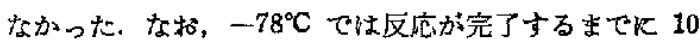
分間要したが，そ扎以後は変化がなかった，室盜の2 $26^{\circ} \mathrm{C}$ で操作を行なっても，充分定量性があることがわかった ので，操作の簡易性などの点を考慮して，以後の実験忙 室温で行疻らことにした。

\section{5. 揮発性脂肪酸 $\mathrm{C}_{1} \sim \mathrm{C}_{8}$ のガスクロマトクラム}

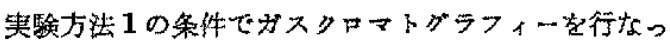
たところ，Fig. 3 のよら良好飞分離したガスクロマ トグラムが得られた。 カラム温度の界盜性，注入時加ら HMDS のどークが現われるむでを $55^{\circ} \mathrm{C}$ 一定とし，それ 以後注每分 $10^{\circ} \mathrm{C}$ 景温上した。显盓条件について $5^{\circ} \mathrm{C} /$ $\min , 8^{\circ} \mathrm{C} / \mathrm{min}$ kついて子検詩したか，分離の程度は

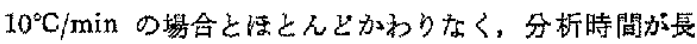
くなるだけであった。またカラム管として，ガラスカラ ムとステンレスカラムについて比較検討したが，前者の

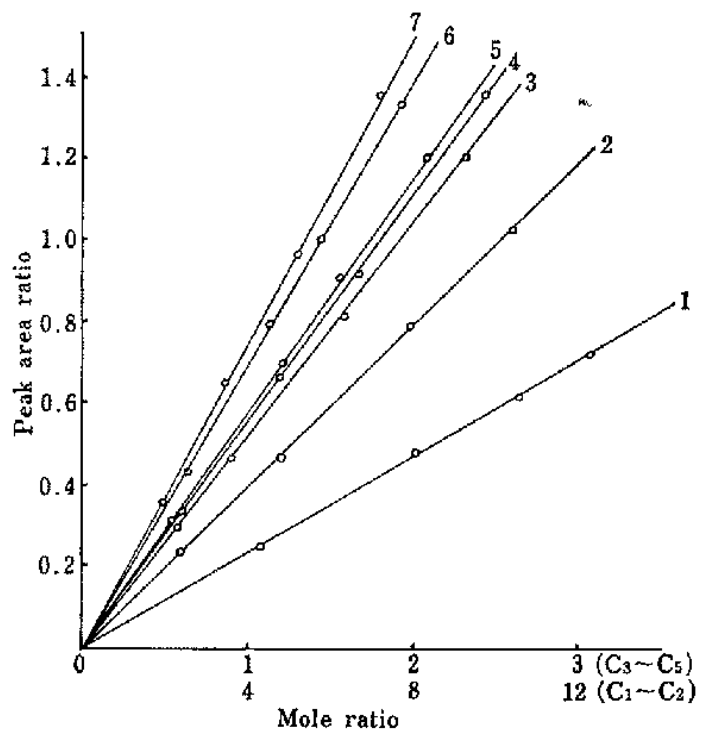

Fig. 4. Calibration Line of $C_{I}$ to $C_{b}$ Fatty Acids.

(1) formate, (2) acetate, (3) propionate, (4) isobutyrate, (5) n-butyrate, (6) isovalerate, (7) $n$-valerate. 


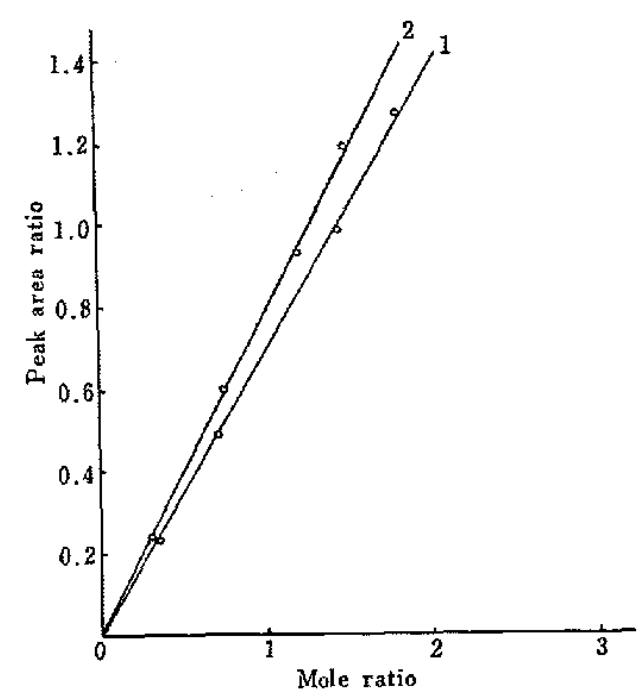

Fig. 5. Calibration Line of $\mathrm{C}_{6}$ and $\mathrm{C}_{8}$ Fatty Acids.

(1) caproate, (2) caprylate.

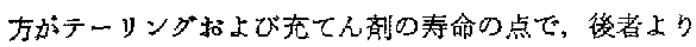

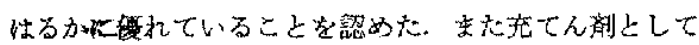
本实琎では，シラン惁理した Chromosorb Wに Sili-

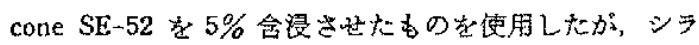
ン未处理の Diasolid L K Silicone GE SE-53を $10 \%$

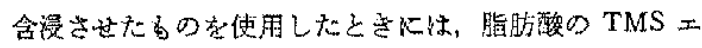
ステルのピークは出現しなかった。和そらく，担体に汉 着されたるのと推察される。

\section{6. 模 量 線}

$\mathrm{C}_{1} \sim \mathrm{C}_{8}$ の各脂肪酸のナトりウム塩瀑合物について， 前記の実験力法にしたがってクロマトグシフィーを行な い, 半鹪幅法によりピ一ク面積比を算出し，3回平的值 をプロットした，その結果を Fig. 4, Fig. 5 に示す。 図方ら明らかなことく， $C_{1} \sim C_{8}$ の各脂肪酸の検甼線は，

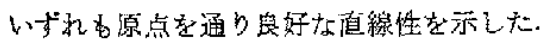

$$
\text { 繁 }
$$

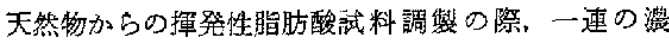
維，㙂水操作ての提头をなくし，操作定容易付すること を考虑して，試料として脂肪酸さトりウム掹を使用し，

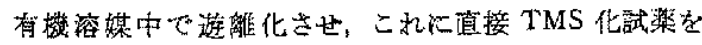
反応をせて，TMS 誘導体として淜定を行なった。 Hunter $S^{(17)}$ は $C_{2} \sim C_{10}$ の脂肪酸ボトりウム塭を, 遊蜼 酸法でガスクロマトグラフ分析を行なっているが，遊離

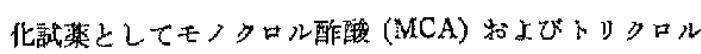

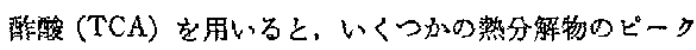

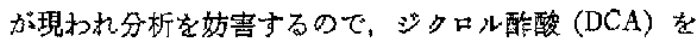
使用したと報告している，本夷駩のよう炕，TMS 化誘 蔀体法火よをと MCA-, DCA- 拈よび TCA ェステルの ガスクロマトグラム上のピークは芳れでれ単一であり， 熱分解物比上ると思われるどーク現和れなかった たがって，遊離化試楽としては三者ともに使用可能であ るが， $C_{1} \sim C_{8}$ 脂肪酸の分析你しては，被娭成方上の分 㲞性加 ら，MCA，DCA 悔ましくなか力た (Table I).

Krebs cycle上の有機酸の TMS 化(12)をはじめとし て, TMS 化反広の溶某として、ピリジンが多く用いら れてきた. しかし本実騃では，ピリジンはプロピホン酸 エステルのピークと重なるために，使用不可能である。

Zinkel ら ${ }^{(14)}$ は，ビリジン溶媒よりも炭化水素系の溶媒 に括ける方か，エステル化率加离いことを報告して和 り，また Shyluk ら (18) は芳香族有㗪酸の TMS 化溶媒 としてナかトンを用いている。この点既して Table II に拀いて，たとえば石油エーテルのモル此（n一酪酸/ナ フタリン=2.53）织，他二者の溶娸のモル此を補正して

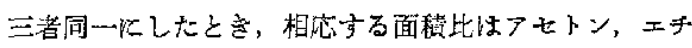

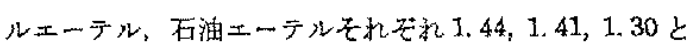
晾り，アセトンが他二者にくらべて、ニステル化率に和

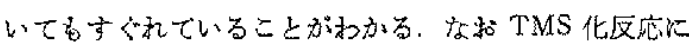
扣いて, 微量の水分の存在性定量性に著しく影響を及心 すので，使用する試料拈よび武薬は完全に脱水される必 要がある。

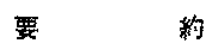

水素炎イオン化㛟出器 (FID) k上り， $\mathrm{C}_{1} \sim \mathrm{C}_{8}$ の揮登 性脂肪酸をトリメキルシリル誘導体として籍易, 逯速に 分析することを試みた。

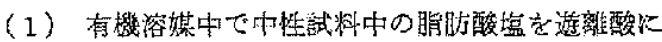

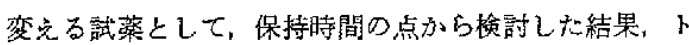
リクロル酶酸が最遥であった。

（2）アセトン中で脂肪酸程は，定量的机遊離ならび にトリメチルシリル化され，上くに低沙点のギ酸和よび

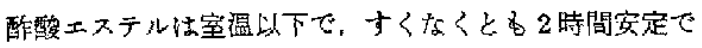
b.

（3） FID K感度のないギ酸含さ $C_{1} \sim C_{8}$ の揮発性 脂肪酸淈合物を一括して，FID型ガスクロマトグラフに 上り，それぞれの脂肪酸を分離上く，かつ社最的に分析 することができた。 
（4）（3）の混合系加ら得られた各脂肪酸の顿量線

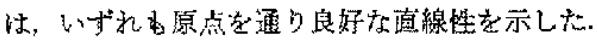

本研究の榴要は，第 135 回日本费荎化学会西日本支部 大会で発表した。

(1) A.T. James and A.J.P. Martin : Biochem. $J ., 63,144$ (1956),

(2) C.W. Gehrke and W.M. Lamkin : J. Agr. Food Chem., 9, 85 (1961).

（3）福为清史，永富英男，村田严郎：分析化学，11, $432(1962)$

(4) A.J. Appleby and J. E. O. Mayne : J. Gas Chromatog., 5, 211 (1967).

(5) M. L. Vorbeck, L. R. Mattick, F.A. Lee and C. S. Pederson: Anal. Chem., 33, 1512 (1961).

(6) L. D. Metcalfe and A.A.Schmitz: ibid., 33, 363 (1961).

(7) B. M. Craig, A.P. Tulloch and N. L. Murty: J. Amer. Oil Chem. Soc., 40, 61 (1963).

(8) J. W. Ralls : Anal. Chem., 32, 332 (1960).
(9) C.C. Sweeley, R. Bentley, M. Makita and W. W. Wells : J. Am. Chem. Soc., 85, 2497 (1963).

(10) P.S. Mason and E.D. Smith : J. Gas Chromatog., 4, 398 (1966).

(11) C.J.W. Brooks and J.G. Carrie : Biochem. J., 99, 47 (1966).

(12) Z. Horii, M. Makita and Y. Tamura: Chem. and Ind., 1965, 1494.

(13) L. Birkhofer and M. Donike : J. Chromatog., 26, 270 (1967).

(14) D. F.Zinkel, M. B. Lathrop and L.C. Zank: J. Gas Chromatog., 6, 158 (1968).

(15) G.E.Martin and J.S. Swinehart: ibid., 6, 533 (1968).

（16）荒本 踆：ガスクロマトグラフィー，菓京化学 闹人，1969，p. 44.

(17) I. R. Hunter, Hawkins NG and J.W. Pence : Anal. Chem., 32, 1757 (1960).

(18) J. P. Shyluk, C.G. Youngs and O.L. Gamborg: J. Chromatog., 26, 268 (1967). 